\title{
Translational Eschatology, Death, and the Absence of God in Rajiv Joseph's Bengal Tiger at the Baghdad Zoo
}

\author{
Stefano Muneroni \\ Dept. of Drama \\ University of Alberta, Canada
}

Received: 25-05- 2013

doi:10.7575/aiac.ijclts.v.1n.2p.1
Accepted: 11-06- 2013

Published: 31-07- 2013

URL: http://dx.doi.org/10.7575/aiac.ijclts.v.1n.2p.1

\begin{abstract}
This essay considers Rajiv Joseph's play Bengal Tiger at the Baghdad Zoo and investigates how it features the complex processes of translation by portraying a translator working in war-torn Iraq during the American occupation of the country. Through an analysis of Jacques Derrida's theories of mourning and translation, it illustrates how the playwright connects translation both to eschatological thinking and to the capacity to speak to/for the dead; the play emphasizes death and translation as in-between states where characters explore aspects of their lives they could not access when alive, and develop skills that allow them to 'translate' themselves in different linguistic and cultural contexts. Through an analysis of the translator as cultural hero and 'stand-in' for God, this essay equates translation with post-secular theological inquiry, and looks at linguistic and cultural translations as acts of faith in which the emergence of the new text is both always in the process of manifesting itself and always predicated on the ashes of the original.
\end{abstract}

Keywords: Theatre, translation, eschatology, bilingualism, Derrida, religion, Rajiv Joseph

\section{Introduction}

The 2011 Broadway production of Bengal Tiger at the Baghdad Zoo showcased Rajiv Joseph as one of the youngest and most exciting voices in playwriting. The play premiered on May 2009 at the Kirk Douglas Theatre in California but it was the Broadway production, directed by Moisés Kaufman and starring Robin Williams in the title role, which put both play and playwright in the spotlight. Joseph was only 37 years old at the time of the New York debut but in spite of his young age he delivered a mature and gripping story set in war-torn Iraq's capital Baghdad in the immediate aftermath of the U.S. military occupation of the country. The play is based on a true incident that took place at the Baghdad zoo in 2003 when a caged tiger tore off the arm of an American soldier who was trying to feed it (Lahr, 2011, p. 76; Anthony, 2007). Joseph employs the ghost of a Bengal tiger killed by a G.I. in Iraq as the disillusioned narrator of the horrors and despair set against the backdrop of a dilapidated city. The playwright's voice is at once unforgivingly glaring and poetic. As the Tiger finds itself wandering through a ghostly Baghdad, the animal engages with the surreal landscape created by the American bombs and interacts with Saddam Hussein's dead son, Uday, two American soldiers, Tom and Kev, an Iraqi prostitute, and finally Musa, a translator for the American troops who is coping with the difficulties of his job while trying to come to terms with the death of his sister Hadia. The plot is quite simple: after the Tiger tears off Tom's arm, Kev shoots the animal dead in retaliation. Immediately the Tiger returns as a ghost and begins to appear to a terrified Kev. Due to his ongoing hallucinations, which make him unfit for combat, Kev is sent to a military hospital where he is visited by Tom who in the meantime has returned to Iraq to retrieve a gold gun and a gold toilet seat he had stolen during the raid of Uday's residence. After Tom refuses to listen to his delirious rantings, Kev in a moment of maddening despair cuts off his arm to feed it to the Tiger, hoping the animal will stop haunting him. After his death, Kev acquires a new sense of self that allows him to understand himself and the world around him better, and to talk to both the living and the dead. Tom, who refuses to leave Iraq without his loot, dies in the desert at the hand of Musa who shoots the American soldier after he fails to deliver the weapons he had promised. Throughout the play, Musa is distraught by the recurring visions of Uday raping and murdering Hadia in the topiary garden where he used to work. Even though Uday has been killed by the Americans, he is very much alive in the play, and continues to taunt Musa by re-enacting the traumatic scene with Hadia.

This essay looks at how the play engages an eschatological view of the world as it ponders issues such as the meaning of life, the existence of God in the face of horrific violence and injustice, and the reality of the afterlife. In his grim representation of decaying humanity, Rajiv Joseph features translation as a frame to address the eschatology of human condition; he showcases translation as a celebration of the death and resurrection of the source language, as transcendental communication across spatial and temporal divides, and as an in-between space of linguistic and cultural negotiation. The play also qualifies translators as spiritual and prophetic interpreters gifted with the capacity to articulate the complexities of living in the modern world, and even as viable 'stand-ins' for God himself. The theoretical frame for the present research comes from Jacques Derrida's famed essay Des Tours de Babel, recent writings about the post-secular philosophy by theologians and scholars, and translation studies theories grounded in deconstruction theory. 
References to the 2013 Canadian premiere of the play, directed by Sandra Nicholls for the University of Alberta's Studio Theatre, will illustrate particular moments of the play and their resonances with translational processes.

\section{Eschatology and Translation}

The New Catholic Encyclopedia defines eschatology as the study of 'the last things', and divides it into two categories, individual and collective eschatology: "Individual eschatology treats of death, in particular judgment, purgatory, heaven, and hell; collective eschatology, of the end of the world, the Second Coming of Christ, the resurrection of the dead, and the general judgment" (Lane, 2003, p. 342). The meaning of the term ties both individual and collective eschatology within the unavoidable ending of life, but it also envisages a projection of new beginnings after death. Bengal Tiger at the Baghdad Zoo considers both types of eschatology through the individual destinies of the characters, who are represented in the midst of a ruined city alternatively as alive, dead, and resurrected, as well as through its inquiries into the scope and future of humanity. In his vision of a world that might be approaching its own extinction, the Tiger questions why God has created him as a predator with the murderous urge to feed on people and asks repeatedly why a just God would allow such violence and destruction to happen. His doubts mirror both personal and cosmological concerns: "What if my very nature is in direct conflict with the moral code of the universe? That would make me a fairly damned individual. [...] I'm guilty! That's why I am stuck here. I'm being punished." (187). Other characters also address death's significance and its transcending power to affect them in the afterlife. As the play contemplates an apocalyptic destiny that is still in the process of fully actualizing itself, it also ponders philosophical and existential issues such as the finitude of life and the complexities of its possible endings, God's participation in man's unhappiness, and, more specifically, whether life is worth living. Rajiv Joseph articulates an eschatological interpretation of life not only through the topicality of his setting and the given circumstances of his characters, but also through his portrayal of eschatology as an intermediary space where temporal demarcations of past, present, and future, and spatial dimensions are bridged. While eschatological thinking happens in the present, its object of inquiry is always imminent. Eschatology makes hypotheses about the future, it represents a trajectory that extends from the 'present of the question' to the 'future of the answer,' intrinsically coalescing temporal and spatial dimensions. For this reason, eschatological reflection always situates itself in a liminal space, in what might be defined as a critical interval intrinsically framed by aliveness and its impending termination. Liminality, as described by anthropologist Victor Turner (1990), "is a no-man's land betwixt-and-between the structural past and the structural future" (11). Turner considers it as a space open to possibilities and changes, as "a gestation process, a fetation of modes appropriate to and anticipating postliminal existence" (12). He associated the limen to the threshold, and described it as existing primarily in the "subjunctive mood of culture, the mood of maybe, might-be, as-if, hypothesis, fantasy, conjecture, desire" (11). In this sense, liminality is the apt mode of existence of eschatological thinking because it coalesces past and future, as well as death and regeneration, in the liminal present. Frank Kermode (1967) argues that this middle position prompts humans' preference for narratives that start and end, due to the fact that for both writers and readers "The End they imagine will reflect their irreducibly intermediary preoccupations" (p. 7). The ending of the play, shown in the death of all of the major characters (the Tiger, Kev, Tom, Uday, Hadia, and the Girl) is not definitive; it is instead a transition into a new life experience. Kev and the Tiger utter in unison their new status as that of being "refracted," a physics' word that describes wave length modulation and its changes in direction, speed, and stability due to a change of medium (Joseph, 2010, p. 215). While there is a degree of stability in refraction, due to the unaltered condition of the refracted object, there is also an expansion in its abilities, which guarantees new possibilities. Refraction depicts quite poignantly Joseph's characters' transformations and their inability to function within binomials and dichotomies. They are dead, but still behave as if they are alive. Death refracts them, or even more poignantly, it translates them into different emanations of themselves. It transforms them to such an extent that they can also easily transcend their geo-political context, speak multiple languages, and access diverse cultural backgrounds. They are the same while being different. The sense of being and feeling intermediary, and their awareness of being situated in between their genesis (their birth) and their apocalypse (their death) extend into their afterlife. In a way, their eschatology continues past their sense of an ending, and into the ending itself. If, as Kermode (1967) argues, the ending allows for attribution of meaning, and that it is the end that transforms chronos, the mere passing of time, into kairos, time that carries the promise of the future, then one can argue that Bengal Tiger at the Baghdad zoo problematizes the idea of ending as termination or conclusion by suggesting that the ending is nothing more than a new beginning (p. 45-58).

This understanding of eschatological reasoning as both present and future activity occurs also in Derrida's philosophical works, especially the ones dedicated to mourning:

We have seen how, for Derrida, the mourning that follows death is prepared for and anticipated even before death [...]. But after the event of death, after the singular event, the loss that had been anticipated risks becoming strikingly present, leveled off, a word, reckoned. [...] The drama, it seems, is not so much that we lose the friend after death but that we can no longer lose them; they who were once so distant become all too close, too close because now only within us. (Brault, 2001, p. 27)

It appears that, for Derrida, death is intrinsically imbricated in the very fabric of life, just as life is part of death's destiny. In his last interview with Jean Birnbaum Derrida (2007) engages Walter Benjamin's notion of überleben (surviving death) and fortleben (living on) to explain his own original understanding of "survival" as "to continue to live, but also to live after death" (p. 26). He confounds the demarcation between being alive and being dead by describing 'survival' as an essential part of Dasein, existence, but also maintaining that "the opposition of life/death 
proceeds [...] from an unconditional affirmation of life" (p. 50). This reading of the interweaving of life and death resonates profoundly within the world of Bengal Tiger at the Baghdad zoo where dead characters continue to live on and form indissoluble relationships with the living. In some cases this bond resembles a ghostly haunting. For instance, Kev dies trying to cut off his arm to feed it to the Tiger who has been appearing to Kev since the day he killed the animal at the zoo. On the other hand, a deceased Kev vexes Tom, who is somewhat responsible for failing to care for him when he was suicidal at the hospital. Lastly, Musa relives the memory of his sister Hadia's murder as a lasting trauma because he feels guilty for having brought her to the topiary garden where he was working. Uday forces him to experience time and again that pain by leading Hadia offstage to murder her on three different occasions. Whether the characters are bound by remorse, revenge, or guilt, they hold on to their lives after they die and their lingering presence deeply impacts the living characters.

The play's eschatological frame defies the Christological paradigm of damnation and salvation which signifies a dualistic trajectory moving from sin to perfection, and spiritual death to eternal life. Instead it counters this paradigm with a notion of the in-between, which swings smoothly from death to life, and back again, and moves just as easily from individual to cosmological reality. Not only are the characters "translated" by death, but they also substantiate translation's power to communicate with the spiritual. Several translation theorists have expressed this bond in clear religious terms: Walter Benjamin (1923/2004) perceives the worth of translation in its providing the source text with an "afterlife" (p. 76), while Derrida (1993) considers the source as a spectral presence, a phantom, that continues to haunt and influence the target text (p. 42-43). In both cases, the target text retains palimpsestic qualities. It is Douglas Robinson (2001), however, who perfectly summarizes the type of translation processes that Bengal Tiger at the Baghdad Zoo so cleverly portrays when he contends that translation resembles "spirit-channeling -communication with and/or mediating for others the spirits of dead people, or, as spiritualist writers like to put it, "discarnate spirits" ( $p$. 21). The characters in the play, in fact, become translators after they die; their bodies operate as channels to convey both the pains and joys of literary and cultural translation. It appears that the "gift of death," to play with the title of Jacques Derrida's book (2008), is for Rajiv Joseph also a gift of translation. Translation partakes of the experience of connecting to the dead and speaking to/for the dead. The characters acquire transcendence the moment they die and show their new status by displaying translational abilities they did not have in life: the Tiger turns, or translates himself, from a wild beast caged in a zoo into a philosophizing being who even manages to temporarily overcome his animalistic tendencies. $\mathrm{Kev}$, on the other hand, finds he is capable of speaking Arabic and acts as a medium between the world of the living and that of the dead, speaking for the leper woman and translating both her words and her pain (p. 233-235). The only exception to this rule is Musa's sister, who cannot stop reliving the scene of her rape and murder because she represents an emanation of both Musa and Uday's shared past, rather than being a character granted her own agency.

With so much emphasis placed on death as an in-between state where characters can explore new aspects of life they did not know, or could not access when they were alive, the questions that come to mind are what kind of translational faculties they display, and what sort of cultural and linguistic transformations enable them to traverse and inhabit two worlds. Derrida's notion of Babel as manifesting both the necessity and impossibility of translation can help unpack the connection between eschatological thinking and translation, and reveal their sophisticated articulations as in-between spaces.

\section{Staging translation and self-translation}

Translation becomes the privileged tool to unpack the theological arguments of the play and to both encode and decode the in-between nature of its characters. Jacques Derrida's seminal essay "Des Tours de Babel" offers a valuable theoretical paradigm to consider the relationship between theological discourse and translation in Rajiv Joseph's play as it looks at the birth of languages, thus the birth of translation, as an act of God. Following Voltaire's understanding of the word "Babel" as both the place where the famed tower was built and as a reference to the name of God as "confusion," Derrida (2002) argues that God sanctioned translation to be absolutely necessary and absolutely impossible. By making his name untranslatable, according to Derrida, "He at the same time imposes and forbids translation" (p. 108). In some regards, God hides in translation, thus making translation the most desirable activity, as it holds the promise of embracing the divine, and the least successful, as no one can find a God who does not want to be found. In spite of the despairing task of translation, however, Derrida argues that there is something hopeful about the promise of reconciliation that translation holds; this promise surpasses the certitude of its unattainability:

As a promise, translation is already an event, and the decisive signature of a contract. Whether or not it be honored does not prevent the commitment from taking place and from bequeathing its record. A translation that manages, that manages to promise reconciliation, to talk about it, to desire it or make it desirable -such a translation is a rare and notable event. (p. 123)

While translation cannot guarantee objectivity, being firmly confined to and by the promise it holds, it also implies an expectation that the terms of the promise will materialize, that the "contract," Derrida mentions above, will be honored. The Latin word promittere, from which 'promise' derives, denotes the action of "sending forth," thus suggesting a degree of movement into the future, an activity that has the potential to impact reality. In brief, translation, as promise, entails a measure of hope that the results will be the ones expected, as well as faith that the translator will be able to accomplish the promise embedded in the source text. Derrida (2002) intimates not only that translation is the privileged medium to speak 'to' and 'about' the sacred, but he also defines translation as partaking of the sacred:

The sacred surrenders itself to translation, which devotes itself to the sacred. The sacred would be nothing without translation, and translation would not take place without the sacred; the one and 
the other are inseparable. In the sacred text the meaning has ceased to be the divide for the flow of language and for the flow of revelation. It is the absolute text because in its event it communicates nothing, it says nothing that would make sense beyond the event itself. (p. 133)

Recent studies about Derrida's deconstruction theory and its connection to theology debunk the incorrect view that the philosopher shares negative theology's belief that it is impossible to speak about God. John D. Caputo (1997) affirms that deconstruction is in reality capable of providing apophatic theology with a language to articulate a discourse about God due to the fact that "Deconstruction is so deeply and abidingly affirmative -of something new, of something coming- that it finally breaks out in a vast and sweeping amen, a great oui, oui -à l'impossible in a great burst of passion for the impossible" (p. 3). Joseph's play's critical fervor for the unattainable, for a communion with God as pure absence, shows the same affirming faith in the unknown that one can see in Derrida's theory. Bengal Tiger at the Baghdad Zoo depicts characters who struggle to develop an apt idiom to articulate their spiritual isolation, and in translation and self-translation discover a means to transcend their predicaments and approach 'a' sense of the sacred.

Translation lies at the core of the play in many meaningful ways: the characters translate themselves and their understanding of the sacred, but they also reside in modern Baghdad, whose city limits include the ancient ruins of the Tower of Babel. Joseph locates them in the very place where languages and translation were born, and leaves them to negotiate themselves and their future, just as in the Genesis story. The focal role of translation emerges predominantly in how the play considers the difficult task of translating languages and cultures for the theatre, and stages the translational process for the audience to experience it. The play reflects on how meaning arises when translation occurs, and how theatre allows for the articulation of cultural and linguistic contents, and contexts, within the theatrical experience. Musa is the moral compass of the story and through him the spectator learns about the traumas of war. As he interprets for the American troops, the audience witnesses the hardships of his profession, those related to the daily interactions with the American soldiers who often come across as rude and culturally insensitive, as well as those immediately connected to the various challenges of translating languages and cultures. Musa embodies the very trials and errors of translating as he confronts the complexity of rendering specific grammatical or syntactical structures, the challenges of having to find circumlocutions to describe specific concepts, or the constant struggle between adhering to the source language while guaranteeing the communicability and speakability of the target language. The first question he asks Kev, in scene 2 of Act I, is "What is 'bitch'?" (p. 155), a question about the jargon usage of the term he heard in a joke and that he cannot find in the dictionary. Musa's confusion, which emerges when he states, "I speak English, but I don't understand casual American," increases moments later when Kev calls him a 'bitch' to describe his subaltern position as an interpreter who sits at a computer instead of fighting in the war.

Scene 3 of Act I is particularly significant in highlighting the frustration and potential risks involved in all translational acts. Kev and Musa encounter two Iraqis with a large wooden chest. The moment is highly-charged because two languages are confusingly being spoken at the same time and because of the potential danger posed by the contents of the chest. The fact that the Iraqi characters speak only Arabic engenders a growing tension in the audience who are equally concerned about the chest and Kev's finger pressing on the trigger of a gun. This scene illustrates how translation contains the possibility for linguistic and cultural conflict as well as its resolution. Kev pressures Musa for a speedy translation while he franticly wields a gun at an Arabic man and woman:

$\begin{array}{ll}\begin{array}{l}\text { KEV: } \\ \text { MUSA: }\end{array} & \text { Wait, what are you telling him? } \\ \text { WOMAN: } & \text { Makoo shee elkoom ehna! Roohoo (There's nothing here for you! Go } \\ & \text { away!) } \\ \text { KEV: } & \text { What are you telling him? } \\ \text { WOMAN: } & \text { Me sawaine shee ghalatt. Roohoo! (We have done nothing wrong. Go } \\ & \text { away!) } \\ \text { MUSA: } & \text { I'm telling him what you said! } \\ \text { KEV: } & \text { What the fuck? } \\ \text { MUSA: } & \text { I'm translating! } \\ \text { KEV (to Man): } & \text { You speak English? Hey, sir, you speak fucking English? } \\ \text { MAN: } & \text { Hathe shee-yreed? Hathe shday-gool? (What does he want? What's he } \\ & \text { saying?) (164). }\end{array}$




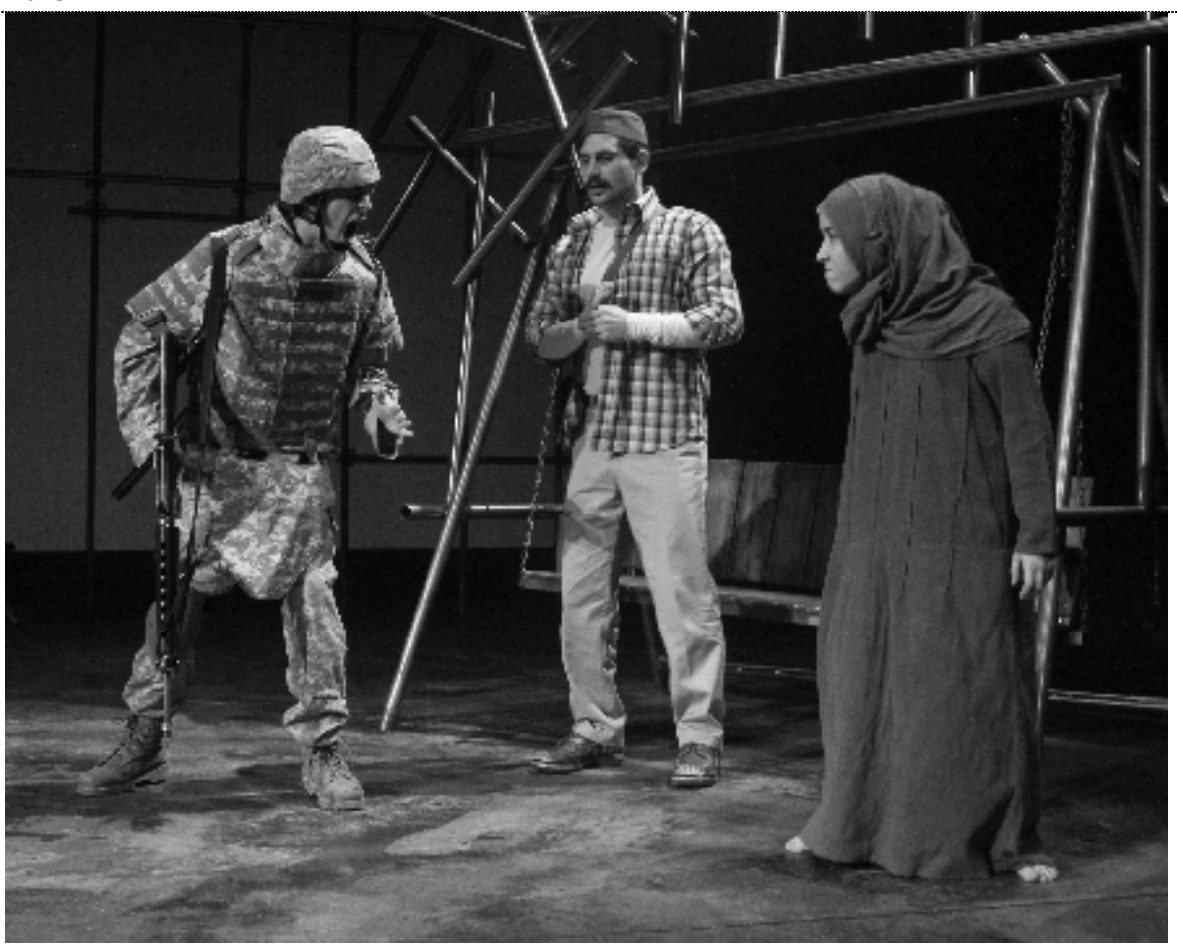

1. Kev, Musa, and Iraqi woman.

Courtesy of the Drama Department at the University of Alberta. Photo by Ed Ellis.

Kev expects the translation to follow a "word-for-word" pattern, and misguidedly assumes that all languages can be mechanically transposed, or reproduced, in the target language (Munday, 2001, p. 19). A moment later Kev's frustration with the procedural and tentative nature of Musa's translation reaches boiling point. Musa cannot remember the English word for "buttaniat" [blankets], which are inside the chest, and Kev begins to fear the chest might contain weapons or explosives. As his anxiety rises, the soldier comes to suspect the translator of plotting against his life alongside his fellow countrymen. The following passage addresses translation's inescapable destiny of conveying either less or more than its source, but never the same, that is, its condition of either under-representing or exceeding the source text:

$\begin{array}{ll}\text { MUSA: } & \text { She says there are .... (To Woman) Shgil-tee (What did you say?) } \\ \text { KEV: } & \text { Wait what? } \\ \text { WOMAN: } & \text { Makoo shee hnak! bess Buttaniat, makoo ghair shee! (There's nothing } \\ & \text { in there! Blankets and nothing else!) } \\ \text { MUSA: } & \text { Nothing! There's nothing. } \\ \text { KEV: } & \text { That's bullshit. She said a lot more than "nothing." I don't speak Iraqi, } \\ & \text { but she said a lot more than "nothing." } \\ \text { WOMAN: } & \text { Yireed il sendoog? Gul-le khelee yakhooth il sendoog! Yakhthe we- } \\ & \text { yrooh! (He want a box? Tell him to take the box! Take it and leave!) } \\ & \text { (166). }\end{array}$

The Italian saying "traduttore traditore," which indicts translation's failure to reproduce the totality of the source text as an act of betrayal, resonates strongly in this scene as it stands for both a linguistic subversion and military treason. The same mistrust occurs in the last scene of Act $\mathrm{V}$ where Uday accuses Musa of having betrayed his own country by being a translator for the Americans: "You, Mansour: a traitor in everyone's midst. [...] You steal from the Americans and you steal from me" (p. 192). In the play, however, the perception of translation as betrayal is mitigated by the etymology of the Italian word "tradire," which derives from the Latin "trahere" meaning also refer, report, relate, thus pointing in the direction of an exchange, a physical act of movement which implies exertion and effort. It is this second accession of the word that defines Musa's translations in the play; he wants to learn English perfectly so that he can do the best work he possibly can, but he is also fully aware that his profession impacts cultural diplomacy and has the potential to foster peaceful conflict resolutions. As an interpreter working in a war zone, Musa understands well the responsibilities of his occupation, and how it exists within the opposition of violence and peace. There is a general obsession with translation as transformation in the play, and with the risks posited by translation, both in literal and metaphorical senses. Musa describes Uday as King Midas, the king who 'translates' everything he touches into gold, but he projects a dangerous connotation onto that reference by linking Uday's predilection for gold objects to the gold gun, which Kev uses to shoot the Tiger and which Musa uses to kill Tom. Uday is also associated with translation as 
violence when he engages in the macabre translation of Hadia into a topiary, and recalls "how she quivered," and how "she burst like a grape" when he dismembered her using Musa's shears (p. 238).

Act II, scene 3, describes another translational conundrum that has the potential to lead to violence and death. When Tom goes back to the leper colony to retrieve the gold toilet seat he stole during the raid of Uday Hussein's palace, he asks Musa to talk to a leper woman to determine the whereabouts of his precious bag which he cannot locate because the building has been bombed. Musa, however, struggles to find a proper translation because he does not know what type of bag Tom means: "What kind! Big bag? Little bag? Luggage? [...] There are different words for different bags!" (p. 226). In a comic twist, when Musa finally translates in Arabic the generic word for bag, the woman replies "What bag?" signaling either that she needs a more specific clue as to the type of bag, or she does not remember Tom's bag at all. The ambiguity of her reply qualifies translation as a difficult process articulated across languages and cultures, instead of as a product resulting from mere word substitutions.

All the translational instances described above remind the spectators of the impossibility of a theory of translation based on equivalencies, where the length of the utterance or the syntax, grammar, and lexicon of the source text will be matched in the translated text. In so doing, it also unmasks the delusion of universal culture readily available and accessible to everyone; instead, it portrays a translator who continues to struggle to negotiate across linguistic and cultural divides, and confronts the paradox Emily Apter (2006) has poignantly defined as the very polarized foundation of translation: "everything is translatable, nothing is translatable" (p. 8).

By suggesting that the source language must be sifted, shaped and delivered through a series of hermeneutical processes, the play indicates the essential role of translation as communication and interpretation. Moreover, the extensive use of bilingualism exemplifies translation as a substantive articulation of any intercultural encounter and as a stepping stone of an intracultural negotiation of foreign content. In the stage directions, Joseph recommends that the Arabic language not be translated in production so as to foster a sense of confusion and displacement. He accomplishes this objective by staging the difficulty of translation and wants the audience to experience it on a sensory level. If the spectator does not understand Arabic, they will have to engage in extra-semantic activities to detect meaning, such as the actors' body language, tone, intonation, and volume, but also the musicality and rhythm of the language. Creative guessing and imagination become key factors in determining what the characters might be saying. The performers' bodies in the context of the entire mise en scène become the site of a translational process entailing inductive and inferential meaning-making processes, as well as inventive fabrications.

It is through bilingualism that the play establishes a powerful connection with the religious concerns raised in the plot, mainly the quest for life's meaning and the role of God in human affairs. From an audience perspective, the play inscribes the experience of foreign language through xenoglossia, the ability to speak a language one has never learned, and glossolalia, a term that refers to languages that are invented in states of religious ecstasy. After his suicide, Kev starts speaking Arabic, a skill he did not possess when he was alive. He states that "I'm like a straight-up braniac in the afterlife" (p. 214), and when Tom asks him how he learned it, Kev replies that "I kind of picked it up in death" (p. 231). When he and other characters speak Arabic, the audience experiences it as a miraculous and transcendent act that partakes of the divine; a gift granted through death to facilitate communication and smoothen cultural differences. At the same time, listening to a foreign language is also an utterly displacing audial experience that carries a sense of incantation similar to that of magic spells, ritualistic conjurations, and prayers; it elicits a mystical communication where meaning is not an immediate given, but must be negotiated through the senses. In this regard, the foreign text hides as much as it reveals. It allows the audience to tune into the rhythm and harmony of its sounds, and it allows them to creatively project what the meaning of the text might be. In scene 2 of Act II, Kev delivers a monologue in an environment that the stage directions describe as a "bombed-out building, half-standing, in the middle of the desert, south of Baghdad. The middle of the night. The place is ghostly, ethereal, haunted" (p. 221). He speaks entirely in Arabic, lifting his "head up, as if to offer it to God." The following is the English translation included in the printed play, but never heard on stage:

God, I am lost in the desert and I am calling out to you in prayer. Because I have never before prayed, I am praying to you in a different language because the very strangeness of it makes me feel like perhaps you would understand. Take my hand, heal my severed body; take me from the desert. Let my mind find peace" (p. 221-222).

In the context of the scene, the foreignness of the Arabic does not thwart meaning-making, instead it provides a rich soundscape to decipher both the unearthly setting and the hieratic tone of Kev's prayer to God. The meaningful physicality of the actor's body, which suggests the brokenness of the character and his spiritual need for the divine, is immediately transparent to the audience. When I saw the play at the University of Alberta's Studio Theatre, I could not tell the specific meaning of the above passage, as I do not speak Arabic, but I found myself imbued in the spiritual context of the scene and felt deeply connected to the emotion it conveyed. Later, when I read the play, which includes the English translation, I realized how much of the atmosphere and tone of the monologue I had been able to detect during the performance by merely focusing on the physical vocabulary of the actor and his vocal choices, as well as the audio-visual elements of the production. In the specific circumstances of the scene, the extraneousness of the foreign language heightened the struggle to reach a spiritual communication with God, and perfectly translated the ruptured identity of the character. 


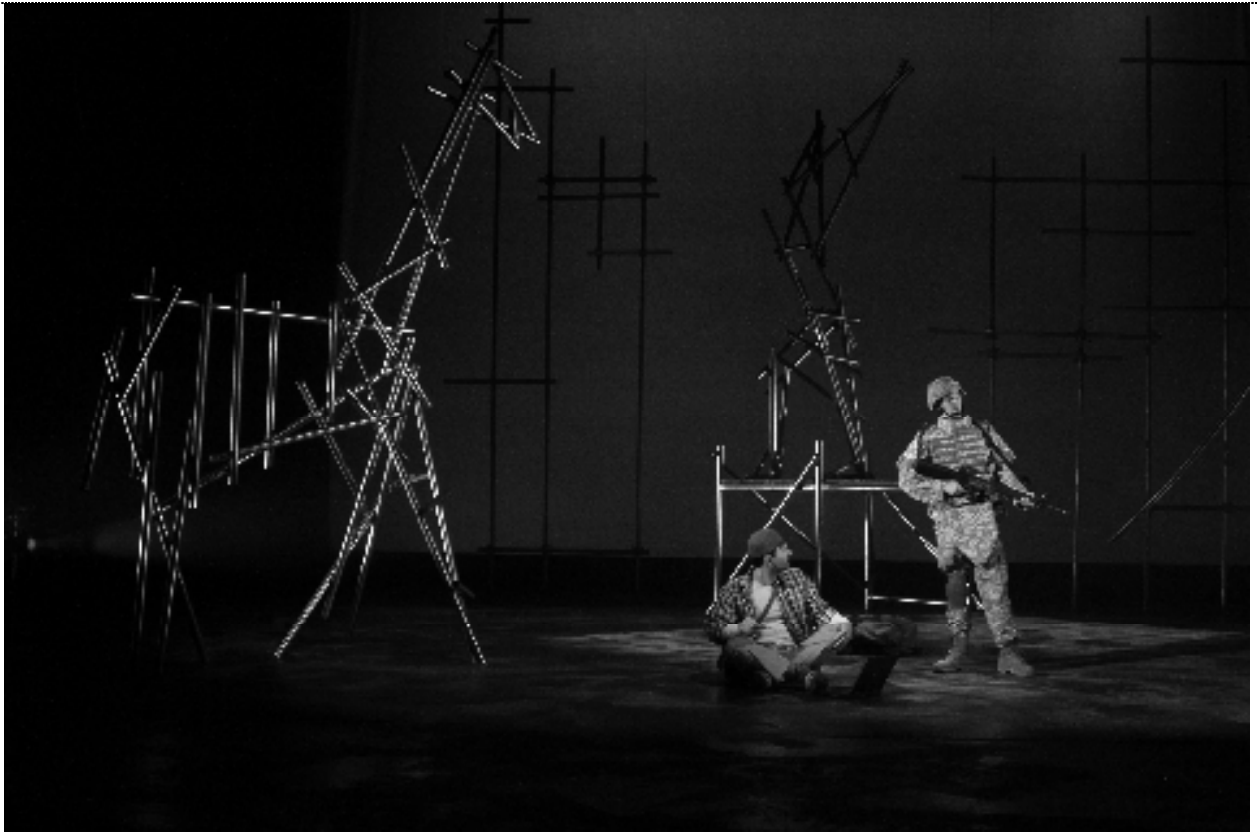

2. Musa and Kev in the topiary garden

Courtesy of the Drama Department at the University of Alberta. Photo by Ed Ellis.

The ability to speak an unknown language also expresses the capacity of the characters to empathize with their fellow men and to understand the world in new ways. Kev makes racist and culturally insensitive remarks in his interactions with Musa while he is alive, but in his death he matures into a sensitive individual who is capable of understanding the pain of others and to be in touch with his most human emotions. The fact that Kev's responsiveness to the Iraqi people manifests itself only after he dies, and only through his translation of their language and culture, connects the act of translating to a ritual of mourning, as much as it posits translation as a celebration of life's possibilities. Jenny Spencer (2007) argues that "[And] like mourning itself, translation is tied to both transformation and loss" (p. 407). As an eschatological function, translation collapses the death and future life of the source language and shows their coexistence. The play re-enacts the incessant struggle of translating by literally showing characters translating themselves in different linguistic and cultural contexts, and addressing the opaqueness of a text that is always emerging and disappearing. Translation bears witness to the inescapable disappearance, a death in itself, of the very object of translation but at the same time it revels in its incipiency. The representation of death, or dead characters, on stage is a common dramaturgical strategy to justify and sustain performance, as suggested recently by Jodi Kanter (p. 28-30), and it inherently denotes death as a channel rather than an end. However, Bengal Tiger at the Baghdad Zoo expands the signification of death as a continuing journey by emphasizing the connection between death and translation, and between translators and God.

\section{Translator as God}

Bengal Tiger at the Baghdad Zoo joins a long list of theatrical works that in recent years have taken on religious themes and characters only to relocate them within a secular framework and investigate how they can signify within and without their original setting. Corpus Christi by Terence McNally, Angels in America by Tony Kushner, The Last Days of Judas Iscariot by Stephen Adly Guirgis, and The Testament of Mary by Colm Toíbín are just a few examples of what is a very long record (Jasper \& Pickering, 2010). Religion has emerged in plays and musicals possibly as an answer to the bleakness of the world's political and economic crisis, or as an attempt to conjugate the wobbly certainties of neoliberal faith with the promise of transcendence of religious faith. In his Notes on a Post-secular Society, Jürgen Habermas (2008) argues that the religious and the secular are no longer in opposition, but are instead intertwined to form what he defines as the post-secular, a new theoretical approach grounded in the belief that post-Enlightenment secularism is over, and supported by an appealing, albeit naïve, faith in human tolerance. In his vision of a just society, Habermas claims that "[...] believers of one faith or another and non-believers must mutually concede one another the right to those convictions, practices, and ways of living that they themselves reject" (p. 23). His perception of tolerance, however, moves past the mere acknowledgement and respect of other people's ideas and probes the possibility for integration. He maintains that secular and religious citizens "must accept an interpretation of the relation between faith and knowledge that enables them to live together in a self-reflective manner," if they truly aspire to build a "shared citizenship" (p. 29).

Graham Ward (2005) argues for a similar integrative model but from a theological perspective. In Cultural Transformation and Religious Practice, he proposes a constructivist view of the future in which proactivity and collaboration enact innovative forms of sociality, and where theological discourse may affect cultural exchanges. Contesting previous theological paradigms, Ward considers the trajectory from sin to salvation not as a unidirectional progression, but rather as an ongoing negotiation happening in the eschatological present. Ward sustains that even 
though Christ's kingdom has already come and "we are already in Christ," salvation is still a condition to strive for in the 'here and now,' and that "there is a working out of the salvation wrought in Christ; there is an incorporation (through a submission) whereby all things are returned to Christ" (p. 169). He explains that "Christian praxis participates in this eschatological incorporation; [...] One might say here that the very operation of the eschatological is the formation of relation, true social relation; for relation can only be realized in the extent to which it participates in the love of Christ" (p. 169-170). In brief, there is a social articulation of salvation that emphasizes the process of working hard to be saved over the result of being saved through Christ's sacrifice. According to Ward, hope "makes present a future doxology, while simultaneously realizing a past promise" (p. 170). In this way, hope also triggers and effects action and intervention by fostering social relations.

Both Habermas and Ward stress a re-contextualization of religious discourse within secular philosophy, as well as a self-reflexivity validated through a collective social practice. Their emphasis on the eschatological present as the inbetween space that bridges the chasms of dichotomical thinking transpires in Rajiv Joseph's play, as well as in many other theatrical works. Theatre's self-reflective nature allows social and cultural ideas to be practiced publicly. Works such as Bengal Tiger at the Baghdad Zoo appear to articulate religious tropes within a secular context, not to simply debunk the theological or biblical appeal of the original source, but to resituate it in a new context so that it may signify on multiple levels. Specifically, Rajiv Joseph questions the value of a God who consents to the atrocities of war and to the indiscriminate sufferings of his creatures. His play is reminiscent of Archibald McLeish's Pulitzer-Prize-winning play $J B$, which is a re-imagination of the story of Job from the Old Testament staged during the Cold War. MacLeish (1958), who sets the biblical tale under a sagging circus tent, portrays God's indifference as cruelty and has JB, his modern Job, discover in the very secular "coal of the heart" his motivation to go on living, instead of finding it in God (p.153). Similarly, Rajiv Joseph counters God's indifference towards human pain with the representation of a humanity that perseveres in the face of an unresponsive God. He offers a humanistic response to God's deficiencies through Musa, the perplexed translator of the story who momentarily operates as God's substitute. When the Tiger encounters Musa in the dilapidated garden of Uday's palace, he believes Musa is God because he has created the striking topiaries representing wild animals. As the topiary artist of a modern Garden of Eden, the Tiger mistakes Musa for the Creator. His ability to translate not only from different languages, but also from different Linnaean taxonomies (from the animal to the vegetable) endows Musa with divine powers, at least in the eyes of the Tiger who is struggling to find satisfactory answers to his existential queries. His interpretation of the garden as an iteration of the original Garden of Eden reveals a disapproving pessimism toward the biblical narrative: "He likes gardens, see. He tests us in them, he tempts us in them, he builds them up and tears them apart. It's like his fucking hobby." Nevertheless, the Tiger still holds on to the belief that God will return to fix his garden, as he says to a little girl who has just lost her life and is terrorized in her new status as dead. When Musa appears, Tiger asks immediately “Are You who I think You are?" (240). The following exchange clarifies how Musa is constructed into a God-like figure due to his translational skills:

TIGER: It's not just me! I brought the girl here. She'd been killed, you know? She was just a little girl. She wanted to know when You'd be back. She wanted to know how You made these things. All these animals. Elephant, horse, giraffe ...

MUSA: This garden is a wound. I want this place to burn, I want to set it on fire.

TIGER: Wait! I mean ... The girl ... She's not going to like that very much.

MUSA: $\quad$ (turns to Tiger) Tell her I'm sorry. Tell her I'm not who she thought I was. Tell her I've done terrible things, and I ... I don't know what I am going to do next. Tell her to forget about me. I've become a different man.

TIGER: $\quad$ You're not a man. You're God.

MUSA: $\quad$ No. I am not.

TIGER: Yes, You are! I've been waiting for You. I've been waiting for You to speak. (p. 241)

The creator of the "vegetative beasts" of the topiary garden refuses to accept the role of God and claims instead that "God has spoken. This world. This is what He's said" (p. 241). Musa can translate, and in so doing he approximates God, but he cannot, and more importantly, he does not want to be Him. Rajiv Joseph restages the myth of the fall from grace within the topiary garden as a metaphor for the world, but he problematizes Eden as the site of man's original sin and God's punishment. He stresses instead human compassion over religious interdiction, and the urgency to continue translating to better understand the world. One of the reviewers of the Broadway production of the play recognized the potential of the garden as a site of human transcendence: "The topiary are at once pre- and postlapsarian, both the cause of the Fall and our redemption from it" (Youngerman, 2012, p. 372). It is in the garden, the world that God has spoken, that the characters must find their reason to be, and they can do that by painfully engaging each other and working out their collective traumas. Translation, as a state of in-between that is both cultural and linguistic, is an essential part of their coming together to articulate their differences and similarities.

\section{Conclusion}

Translation's eschatological process occurs within a post-secular realm where the emphasis is placed on human solutions. The play ends on a dark note when Musa, who has been struggling to keep his humanity for most of the play, finally loses it when he shoots and kills Tom. However, in spite of his difficult circumstances, Musa still holds on to the 
hope for transcendence. He reclaims his agency even though he knows he might have to live with his ghosts forever. Talking to Uday, who has just exited to re-enact the murder of Hadia ("to take her back there and make her into a topiary"), Musa says: "I will live with your voice, okay? I will live with it. It doesn't matter, because my hands belong to me. And my hands have their own memories. And when I put them on a plant, they create something. They will create something" (p. 240). The idea of creation is inherently tied to that of survival and provides the character with a sense of the future. The act of translating animals into plants, which functions as a metaphor for both literary and cultural translation, provides transcendence because it initiates a dialogue with the divine. This divine, however, is located profoundly in the humanist view of the play, and in a post-secular understanding of the world, where men must cope in a Godless universe. Musa's statement that the world is nothing but God's will is less a despairing ending than it is an invitation to rebuild what is broken (p. 241). It heralds the possibility of a fulfilling future the very moment that it claims the world to be a mere tabula rasa. Reflecting on the iconoclastic stance of modern art, Mircea Eliade (1964) considers the idea of destruction as necessary to rebuild a new world, and as "the hope of creating a new universe, more viable because it is more true, that is, more adequate to the actual situation of man" (p. 84). Eliade argues that periodical annihilation in cosmic religions restores the "virtuality" of the world by effecting and accelerating future creations. This notion of virtuality appears to describe closely the spiritual potentiality in Bengal Tiger at the Baghdad Zoo, where human decay is always accompanied by possible regeneration: "Joseph's male characters may be created in sin, but they can at least contemplate change" (Youngerman, 2012, p. 372). It appears that change is available through translation as a strategy of communication but also as a means of rediscovering the transcendence of humanity. As a "hope of reconciliation," translation holds the key to initiating a communication with the theological and the spiritual (Spencer, 2007, p. 409). Through its demythologization of biblical tropes and its insistence on the urgency to continue translating, the play fosters a "religion of humanity" that conceives of man as both divine and an image of the divine (Woodhead \& Heelas, 2000, p. 70). It reconfigures the hierarchy of divine/human and deconstructs cultural and theological discourses. As it exposes the culpabilities of God, Rajiv Joseph's play features translation as a tentative yet inescapable step toward a new articulation of the sacred in a post-secular frame.

\section{References}

Anthony, L. (2007). Babylon's ark: The incredible wartime rescue of the Baghdad zoo.New York: St. Martin Press.

Apter, E. (2006). Translation zone: A new comparative literature. Princeton: Princeton University Press.

Benjamin, W. (1923/2004). The task of the $t$ ranslator. Zohn, H. (trans.). In Venuti, L.(ed.) The translation studies reader (second edition). London and New York: Routledge, 75-85.d.)

Brault, P. Naas, M. (2001). To reckon with the dead: Jacques Derrida's politics of mourning. In Derrida J. The work of mourning. Chicago: University of Chicago Press, pp. 1-30.

Caputo, D. J. (1997). Prayers and tears of Jacques Derrida: Religion without religion. Bloomington: Indiana University Press.

Derrida, J. (2008). The gift of death and Literature in secret. Chicago: University of Chicago Press.

Derrida, J. (2007). Learning to live finally: The last interview. Brault, P. \& Naas M. (trans.) Brooklyn, NY: Melville House.

Derrida, J. (2002). Des tours de Babel (trans. J. Graham). In A. Gil (ed.) Acts of religion. New York: Routledge.

Derrida, J. (1993). Spectres de Marx: L'état de la dette, le travail du deuil et la nouvelle Internationale, Paris: Galilée.

Eliade, M. (1964). The sacred and the modern artist. In Mircea Eliade: Symbolism, the sacred, \& the arts,. Ed. by Apostolos-Cappadona, D. (1988). New York: Crossroads.

Habermas, J. (2008). Notes on post-secular society. New Perspectives Quarterly, 25, 4,17-29.

Jasper, T. and Pickering, K. (2010). Jesus center stage: Theatre, radio, church, TV. Godalming: Highland Books.

Joseph, R. (2010). Three plays: Gruesome playground injuries, Animals out of paper, Bengal tiger at the Baghdad zoo. Berkeley: Soft Skull Press.

Kanter, J. (2001). Death becomes performance: The reciprocal usefulness of death and performance. Theatre Annual $54,25-42$.

Kermode, F. (1967). The sense of an ending: Studies in the theory of fiction. New York: Oxford University Press.

Lahr, J. (2011). Tooth and Claw. The New Yorker, 87, 8, 76-77.

Lane, D. A. (2003). Eschatology. In New Catholic Encyclopedia, vol. 5, $2^{\text {nd }}$ ed., Detroit: Gale, 342-352. Retrieved from http://www.ualberta.ca

MacLeish, A. (1958). JB: A play in verse, Boston: Houghton Mifflin Company.

Munday, J. (2001). Introducing translation studies: Theories and application. New York: Routledge.

Robinson, D. (2001). Who translates? Translators subjectivities beyond reason. Albany: State University of New York Press.

Spencer, J. (2007). Performing translation in contemporary Anglo-American drama. Theatre Journal 59, 389-410. 
Turner, V. (1990). Are there universals of performance in myth, ritual, and drama? In Schechner, R. (ed.) By means of performance: Intercultural studies of theatre and ritual. Cambridge: Cambridge University Press.

Ward, G. (2005). Cultural transformation and religious practice. Cambridge: Cambridge University Press.

Woodhead, L. \& Heelas, P. (2000). Religion in modern times: An interpretive anthology. Oxford: Blackwell Publishers.

Youngerman, E. (2012). Bengal tiger at the Baghdad zoo. Performance review. Women \& Performance: A Journal of Feminist Theory, 22:2-3, 371 